Research Article

\title{
The culture of Inno-preneurs vs. human capital investment in developed countries
}

\author{
Mohammed Meri \\ University of Strasbourg - Laboratoire Sage \\ Correspondence: mmmeri@unistra.fr; mhdmeri@gmail.com
}

\begin{abstract}
In the age of new technologies and globalization, individual and organizational ideas are different. New ideas and new practical models are developed for socio-economic purposes. The vision of entrepreneurs evolves because the first reflections have been centered on the idea of the individual and his behavior which can only be revealed by him, but companies can concretize new cases of innovation. The term 'entrepreneurship' has become a bit old-fashioned; the new style of managerial behavior is called 'the culture of Inno-preneurs'. This study is based on a theoretical framework and on a conceptual, analytical methodology for tackling the subject of Inno-preneurs in a deep way (concept and definitions, characteristics, leadership, roles in organizations v. entrepreneurship, culture and behavioral spirit of innovation, models, real cases) and finally it proposes a practical model.
\end{abstract}

Keywords: culture of Inno-preneurs; human capital; development.

Resumen: En la era de las nuevas tecnologías y la globalización, las ideas organizacionales e individuales han cambiado. Nuevas ideas y modelos prácticos son desarrollados con fines socioeconómicos. La concepción sobre los emprendedores ha evolucionado debido a que las reflexiones iniciales estaban fundamentadas en una idea del individuo emprendedor y su conducta que solo él podía revelar, pero ahora las empresas pueden concretar nuevas prácticas de innovación. El término 'emprendimiento' se ha vuelto algo anticuado; el nuevo estilo de conducta gerencial se llama 'la cultura de los inno-emprendedores'. Este estudio está basado en un marco teórico y una metodología conceptual y analítica para abordar la temática de los inno-emprendedores de una forma profunda (concepto y definiciones, características, liderazgo, roles en las organizaciones frentes al emprendimiento, cultura y espíritu del comportamiento de innovación, modelos, casos reales) y finalmente propone un modelo práctico.

Palabras clave: cultura de inno-emprendedores; capital humano; desarrollo.

\section{Introduction}

Scientists and practitioners have proposed multiple concepts and definitions to the theme of innovation + entrepreneurs (or Inno-preneurs) according to their disciplines and approaches as well as their experiences. Entrepreneurship and Innovation are currently concepts that occupy a 
central place in the understanding of the development of the economy and contemporary societies. In the age of globalization and the Internet, leaders must explore ways to enable a viable and profound socio-economic transformation to create a prosperous and sustainable future. In recent years, the hybrid term "Inno-preneurs" - the translation of innovative ideas into successful business projects - has been used to express these essential elements of the competitiveness and success of companies, cities, and businesses in country. This term could offer a useful perspective for thinking about socio-economic development. In this way, such a country begins the work necessary to bridge the gap between rich and poor to ensure that the needs of both are considered and those effective solutions and capacities are developed. While innovation requires a process of reflection and action to respond to specific current and future needs, innovation is the metaphorical scheme upon which a developed country is constructed by visualizing something that does not yet exist, working for people who do not know it yet. They want the services and opportunities offered by innovative companies and administrations. People for commercial and societal purposes develop new ideas and new technologies. The vision of innovators and entrepreneurs is changing rapidly, because the initial ideas were very much focused on the idea of the innovator or the individual entrepreneur, the creator of a company and the situation in which he found himself; However, entrepreneurship is not simply a set of behaviors that can be presented not only by individuals, but also by large companies able to invest these ideas in the development of the country and companies. New ideas are launched, and we can see how this is reflected in economic vitality and social life in the broad sense. This is where the innovator focuses on solving business problems, exploring, organizing people, and acting often without full authority.

Le Maire (2013):

"Bill Gates said about the concept of Inno-preneurs: We always overestimate the change that will occur in the next two years and underestimate the change that will occur in the next ten. I believe that the essential relationship between entrepreneurs, innovation and economic activity is evident, but the idea of where entrepreneurs and Inno-preneurs fall is not so relevant because the competitive edges are harder to define and protect, though the online world does speak directly to the notion of creative destruction, whereby, for example, online retailers have used their innovation to beat bricks and mortar retailers."

HEC Montréal (2008) defines "Entrepreneurs are components of (1) Innovation and (2) Creators, techno-preneurs, intrapreneurs, extra preneurs."

Hisrich (1990) in American Psychological Entrepreneurship defines "Entrepreneurship is the process of creating, not mind the store but is playful and irreverent." Dictionnaire Larousse Français describes: The general and abstract idea that the human mind has of a concrete or abstract object of thought, and which enables it to relate to the same object the various perceptions that it has of it, and to organize its knowledge. Is the right way a business is designed, a general idea and a project?

Termium Plus, The Government of Canada's terminology and linguistic data bank (1992), defines:

"[inno-preneurship] is a roll-up-your-sleeves guide that directs you in conducting fruitful brainstorming sessions and demolishing mental blocks; weeding out the good ideas from the bad, before you blow the bank on them; forming a good team to work with on a project; developing a step plan to bring your innovation closer to reality; documenting your ideas." 
Lengsfeld (2019) wrote:

\begin{abstract}
"Inno-preneurship is defined as the teaching and practice of entrepreneurial action aimed at the implementation of new technical organizational or scientific findings into marketable products and services as well as their successful establishment as novelties within the market. The word inno-preneurship refers to the teaching and practice of a certain type of entrepreneurial action that comprises all processes at generating new knowledge, at bringing them on the market and thus at making them accessible to many potential users. At its core, inno-preneurship is about trying innovation into and new source of value creation".
\end{abstract}

The Bison Gear \& Engineering Corp defines: “Inno-preneur combines creative power transmission and motion control application engineering expertise with product development skills/competencies and a solid business background to enable OEM's to expedite the successful implementation of creative ideas into new product lines or business entities" (Innovpreneur, 2012).

Beckford Consulting (1992) defines:

"A process through which those with entrepreneurial inclinations can assess their corporate renewal, intrapreneurial. Organizations need to regain their entrepreneurial spirit and release disruptive thinking engagement and motivation as it instills a sense of meaning and purpose in .... Any organization looking to become entrepreneurial needs to ... allows the creative process".

EUCIS-LLL 2000 Lisbon Council defines entrepreneurship and intrapreneurship as "the process of uncovering and developing an opportunity to create value through innovation" (EUCIS-LLL, 2000). This definition of entrepreneurship is useful for the emphasis it places upon: ... Of course, higher education can help students develop an entrepreneurial cast of minds.

Morrison (2000) writes creative thinking processes within the context of entrepreneurship education, effectuation, entrepreneurship education, intrapreneurship, creativity.... creative thinking may be defined as "a set of behaviors, attributes and skills that allow to open the mind and know there is a world outside with other cultures.

Le Maire (2013) defines the concept :

"A new frontier of this innovative business model activity could be the idea of sustainability in human resources, and the implications for both innovators and existing businesses. As innovopreneur, or initiator, you must be faster than ever. There is an identifiable relationship between entrepreneurship, inno-preneurship and innovation, and one that can be observed within the economic environment internationally."

As the Inno-preneurs knows, every "solution" must be taken apart and added to, over and over, as questions arise, especially about socio-economic jurisdiction issues. It is here that the Inno-preneurs vision presents challenges if partnerships and funding have not been identified and deals sealed before collective decisions are made. Inno-preneurship grows into partnerships between innovation managers, economic development managers, government departmental heads, academic institutions, OEMs, SME implementers, the private sector, entrepreneur incubators and venture capitalists or angel funders and to other aspiring Inno-preneurs. In this 
way, ideas and funding are spread broadly, encouraging an inno-preneurial mindset - the key to future economic success (Yu-Jen Chen, Karuri-Sebina ,2017).

The main objective of this research is to highlight the concepts of the Culture of Innopreneurs vs. human capital investment in developed countries.

The sub-objectives are such:

1) Introduce the Culture of Inno-preneurs vs. human capital investment in developed countries to address this topic.

2) Illuminate applied models of several approaches.

3) Propose a New Practical Model for Culture of Inno-preneurs vs. human capital investment in developed countries.

The research addresses the following issues and problematic:

- What are the successful models in applying the Culture of Inno-preneurs vs. human capital investment in developed countries?

- What is the impact of the Culture of Inno-preneurs in human capital investment in developed countries?

- How to develop and implement a practical model of the Culture of Inno-preneurs vs. human capital investment in developed countries?

\section{Methodology}

To complete this research, we followed an exploratory, comparative, and qualitative methodology, by studying and analyzing theoretical and practical studies and research already done on the subject and making extracts from their results in order to approach the subject and add a scientific contribution to this field. The studies mentioned and analyzed have rich content (concepts and models), which was oriented towards and enriching this research.

\section{Theoretical Framework}

The theoretical framework and the hypothesis of research are schematized as the following:

Figure 1. Theoretical framework.

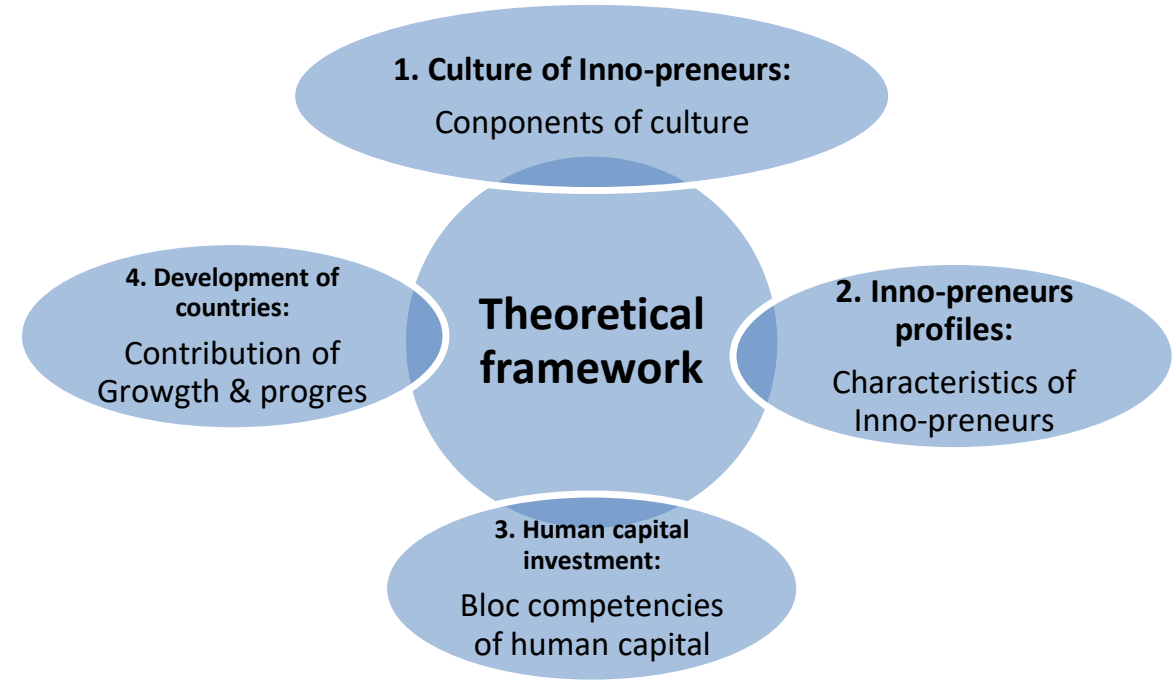

Source: Produced by the author. 


\section{Inno-preneurs' characteristics}

The entrepreneur is a pioneer of sorts. Their job is to create a sustainable and a profitable business by discovering markets that need serving. Usually, this would be in the form of a problem encountered or perhaps an unfulfilled market needs or a gap in the market. In such a circumstance, the entrepreneur endeavors to provide a solution. This could mean coming up with new (or better) products and services that fulfill the need foreseen by the entrepreneur. A business model is then created; this could require establishing a team, enterprise, or company to ensure business operations run smoothly. This can make entrepreneurship a risky venture to undertake. Market uncertainties, limited resources and even, personal capability contribute to making entrepreneurship a hard marathon of uncertainty and risk. And of course, there's also competition. It is no surprise that the main challenge faced by entrepreneur is how to do it better. How to make one's product stand out and provide better value than competitors? Emulating competitors or following existing methods will not result in a distinctive business. It simply produces 'me too' products. Similarly, repeating methods while expecting better results is counterproductive. Hence, the question: if the entrepreneur desires progress, what can they do? We have an answer. They could embrace change as a positive and could adopt an innovative mindset. We call this being an 'Inno-preneurs' (Hello-world, 2016).

The trait of innovativeness is an inclination to create a positive change to the way things are. For the Inno-preneurs, this means seeing the status quo as malleable, not fixed. Change is a good thing with positive outcomes. As a result, the Inno-preneurs comes up with ideas that enhance an existing product, system, or process. For the entrepreneur, adopting the Inno-preneurs mindset can be a powerful business definer. It enables one to create better solutions, improve products and services, and creatively solve problems. Applied to a business, it can result in products with impact, higher value, and a competitive edge. Alternatively, the Inno-preneurs mindset can be used optimize a company's operations. Previous practices can be improved on for a more conducive working environment. Teams can be managed more effectively, fostering cohesiveness with higher productivity. (theinnopreneurs.com,2016).

Metrix Research explains: "The list is endless on what the Inno-preneurs mindset can do for the entrepreneur. A positive game changer, the Inno-preneurs mindset can help entrepreneurs improve the way their business is conducted. And it can be learned" (Metrix Research. The Entrepreneur, s Journey)

INNO-PRENEURS is a yearly contest hosted by Lemon Ideas. It is much more than a conventional B-plan contest. It is a national level platform that encourages individuals, students, and professionals to bring ideas and innovations for others to know.

\subsection{Inno-preneurs = Innovation + Entrepreneurs}

Inno-preneurs are entrepreneurs who wish to grow altitude wise tasks of different levels of abstraction and specificity. At the highest altitude, you are asking the big questions:

Table 1. The big questions of highest altitude of Inno-preneurs.

\begin{tabular}{cl}
\hline Questions & \multicolumn{1}{c}{ Description } \\
\hline 1 & What are we doing technology wise? \\
\hline 3 & What are we doing to increase user experience? \\
\hline 4 & $\begin{array}{l}\text { What is the next innovation we will bring to the table? } \\
\text { impact? }\end{array}$ \\
\hline 5 & $\begin{array}{l}\text { At the lowest altitude, you are looking at on-the-ground operations: } \\
\text { Did we convert the client? }\end{array}$ \\
\hline
\end{tabular}




\begin{tabular}{cl}
\hline 7 & How much did we make with the last sale? \\
\hline 8 & How many registrations we did last month? \\
\hline
\end{tabular}

Source: City University of Hong Kong, 2017.

Inno-preneurs is divided into 4 preliminary rounds prior to the Grand Finale. The top 3 winners of these rounds will be promoted to the Grand Finale. These rounds are:

Table 2. The 4 preliminary rounds of inno-preneur.

\begin{tabular}{cc}
\hline Orange Round & Green Round \\
\hline White Round & Chakra Round \\
\hline
\end{tabular}

Source: India's Most Happening, 2018.

\subsection{Inno-preneurs: Leader in Organizations}

As an Inno-preneurs leader, being anticipative rather than simply agile is the key to today's leaders. Make the future more visible by:

- Examine the nature of cyclical changes (e.g., stock market cycles) versus linear changes (e.g., changes in music consumption).

- Identify the difficult trends that will occur (for example, how people watch television).

- Look outside your industry for the solutions you need, it is preferred.

- Focuses on harnessing innovation, technology and lessons learned from outside your industry (Innovpreneur, 2012).

Innovpreneur explains decisions by five quick steps:

1) Embrace fact-based decision-making

2) Think like a Dr. by diagnosing the problem

3) Start with questions - not answers

4) Collect data

5) Then, make decisions (Innovpreneur, 2012)

Innovpreneur explains the $3 \mathrm{C}^{\prime} \mathrm{s}$ of disruption and innovation by the CEO of Mandalay Entertainment (Golden State Warriors NBA team and LA Dodgers major league baseball). They are:

1) Culture (risk tolerance)

2) Collaboration (execution on ideas)

3) Curiosity (the driver of reinvention) (Innovpreneur, 2012)

At the same time, Innovpreneur, explains who an innovation leader and intrapreneurship careers are, and what innovators can learn from a case study based on Gatorade. Interestingly, innovation flowed from Bangladesh in an example of innovation flowing "uphill" from developing countries. The most interesting steps are:

1) Globalization

2) Designing global products for local markets from scratch

3) And finally, level with reverse innovation (Innovpreneur.com, 2012)

Marla Gottschalk suggests four ways to tackle the challenge. As organizations grow, they become less flexible and nimble:

1) Leaders should embrace different perspectives

2) Sharing information with the right people (versus just collecting it)

3) Tap the knowledge of those around you (employees are a good start)

4) Maintain the ability to swarm (assemble quick teams) (Innovpreneur.com, 2012) 


\subsection{Role of Inno-preneurship in Organizations}

Inno-Preneurship plays a significant role in the social and economic development of any nation. Historical facts show that Inno-preneurs are the engines of economic growth. They have been and continue to be critical contributor to the economic growth through their leadership, job creation, competitiveness, productivity, and formation of new industry and services ventures (Kuratko, Morris \& Schindehutte, 2015). According to Berna (1960) Entrepreneur is the organizer of society's productive resources. Thus, every entrepreneur plays a crucial role in the organization and use of society's productive sources. He procures and allocates the physical, human, financial, technological, and informational resources, in the best interest of all the sections of the society.

\subsection{Entrepreneurship and innovation}

Heller in Benoît Lévesque et al (2008) asks a more basic assertion that we should simplify our language in speaking about innovation and focus on the reducing the delineation between innovation (new) and core (old) business and ideas. She points out "Creativity, clarity of purpose and social responsibility should never be someone 'thinking beyond their job description.' In fact, only when it is their job description will we see lasting change, happier employees, and healthier companies" (Lévesque, 2008).

The distinction between entrepreneurship and innovation is slightly off in today's world, the key entrepreneurial activity is innovation; not separating the two as distinct entities. The two are contingent upon one another as entrepreneurs make innovation happen, it might be simpler to suggest that entrepreneurs are the innovators (Inno-preneurs) in terms of behavior. The term entrepreneurship has become slightly old-fashioned, as it seems to cover a huge range of activities, and a huge range of people and organizations, it has become a trend/style. This almost makes the term entrepreneur redundant, as it now be many things; it may be even useful to set a distinction between entrepreneurs as people, and entrepreneurial style activities that are more engaged in businesses. Entrepreneur, Inno-preneur, HRpreneur, Financepreneur etc... (Le Maire, 2013).

\subsection{Passion and Spirit of Innovation}

Passion is a real driving force that contributes to personal and professional growth. It is an intense and irrational affection, which lives and cannot be explained rationally. That said, being passionate does not mean, by nature, being talented, yet passion provides the strength, motivation, and courage to go to the unknown. Being passionate about something can you find the time and the means to learn and try constantly? Passion makes you dream at the same time of being scared, questions jostle in your head, and it is quite normal, it is not easy to leave the frame or the box, to do not like the others and to venture in search of talent and its business potential.

Here are some steps to help people turn passion into business in the workplace. There are six steps to transform passion into business innovation such as:

1) Identify what you are passionate about: Flaubert Gustave (1821-1880), a French writer, considers that "to have a talent, you have to be convinced that you have some".

- Identify your talent or passion is the first step.

- Document yourself: by reading, watching videos, or listening to radio shows on topics that interest you; Go to others, discover, test, participate in introductory workshops, go to different places, and interact with people very different from you.

2) Developing Self-Confidence: Self-worth is built over time, and with every step you take to achieve your passion, your project builds and builds the confidence you need. 
3) Be creative: To do something different, to be creative is to be unique. Creativity is not just for artists or inventors, it is about each of us in our daily lives, in the way we see things and those with which some people face situations.

4) Follow the trends: look for inspiration, be trendy and considerate trends and fashion and their evolution.

5) Test the products: Test similar products/services that are marketed for a better knowledge of its technical specificities. Test your products: taste, try, use... depending on the nature of your product by the public concerned.

- Valuing your talent: To have a remarkable and aptitude in an intellectual or manual field and to be gifted is an infinite and inexhaustible resource. To exploit it to its true value can only create wealth and value for you and the others (Inno-preneurs.com,2017).

\subsubsection{An Inno-preneur: A Success in Business and Life}

According to Mootee (2013), these enterprising people align their passion with corporate objectives to identify new ideas and create significant value to help grow the organization. Design Thinking for Strategic Innovation presents a framework for design thinking that is relevant to business management, marketing, and design strategies and provides a toolkit to apply concepts for immediate use in everyday work.

Corporate inno-preneurship requires the following attributes:

Table 3. Attributes required by corporate inno-preneurship.

\begin{tabular}{cl}
\hline Attributes & \multicolumn{1}{c}{ Description } \\
\hline 1 & A leader that are comfortably to act without authority \\
\hline 2 & $\begin{array}{l}\text { A design thinker that enjoys solving complex business challenges } \\
\text { with limited information }\end{array}$ \\
\hline 3 & $\begin{array}{l}\text { A manager who understands his everyday job is to resolve } \\
\text { dilemmas and not just dreamers }\end{array}$ \\
\hline 4 & An explorer who can navigate even there are changes in scenarios \\
\hline 5 & $\begin{array}{l}\text { An organizer who can manage people and resources in an agile } \\
\text { manner. Every company needs a few of these to achieve innovation- } \\
\text { led growth }\end{array}$ \\
\hline
\end{tabular}

Source: Mootee, 2013. Adapted by author.

Shinu Anna Abraham et al. (2013) propose some questions about innovation and Innopreneurs such as:

1) Why Innovation is so Hard for Leaders: Most business leaders do not understand what makes innovation so different from everything else they do at work - and they have not adjusted their behavior to accommodate these differences.

2) How to Find Champions of Innovation Among Your Ranks: The search for an innovation champion often begins internally for someone who is a confident leader comfortable working in an unstructured environment, capable of thinking creatively and a genuinely good listener.

3) Mural.ly, A Stunning Wall in Which to Grow Ideas Together: Mural.ly is a new webbased application that lets you create your own virtual bulletin board, posting and arranging inspiring images, notes and more to spur your imagination. It also enables small teams to collaborate on murals, bringing a new dimension to team creativity.

4) Sparks and Experiments: The Right Way to Manage and Execute Side Projects: There are clients to serve, deadlines to make. One ad agency has come up with a clever process to capture ideas, identify the best ones and conduct creative experiments. 
5) How Smart Companies Welcome and Anticipate Creative Friction: All firms have strategies and cultures. But sometimes the quickest and surest way to gain valuable insight into their fundamentals is by asking, "What's the most important argument your organization is having right now?" (Shinu Anna Abraham et al., 2013).

\subsubsection{Behavior of the Inno-preneur}

Inno-preneurs is a national level platform that encourages individuals/ students/ professionals to bring ideas, innovations to the platter for others to devour. This figure shows below the behavior of Inno-preneur.

Figure 2. The behavior of the Inno-preneurs.

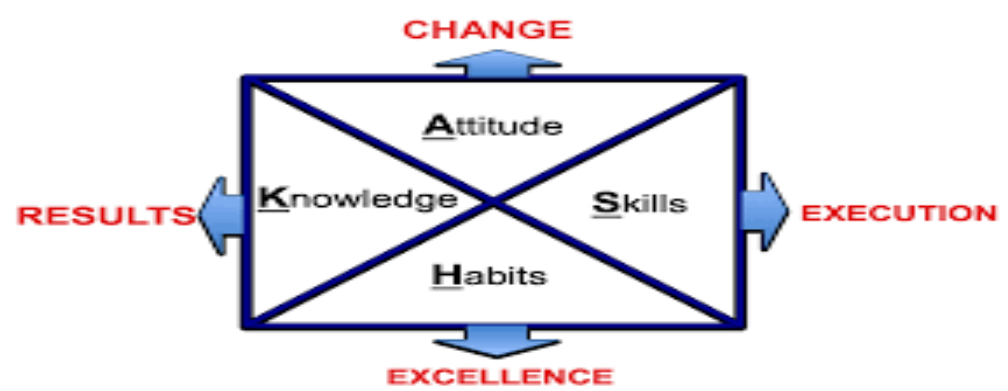

Source: womeninfocus.com

\subsubsection{The Culture of Innovation}

Innovation culture can be defined as the set of habits, behaviors, codes, images, and myths shared by members of an organization related to innovation. To describe this culture, there are three analogies are possible:

1) Culinary: what ingredients for an innovation culture?

2) Environmental: what is an innovative ecosystem?

3) Organic: what is the DNA of an innovative organization?

The ingredients of the innovation culture. Dobni (2008) proposes four ingredients to observe to describe an innovation culture:

Table 4. The four ingredients that describe a culture of innovation.

\begin{tabular}{|c|c|}
\hline Ingredient & Description \\
\hline 1 & $\begin{array}{l}\text { The intention to innovate is measured on two levels: } \\
\text { - Identification of innovation in the structure, strategy, and } \\
\text { processes. } \\
\text { - Employee engagement in innovation. }\end{array}$ \\
\hline 2 & $\begin{array}{l}\text { The favorable framework, which manifests itself via: } \\
\text { - Organizational learning ability. } \\
\text { - } \quad \text { Creativity, freedom, and empowerment of employees. }\end{array}$ \\
\hline 3 & $\begin{array}{l}\text { Operators' behavior, which must reveal two points of interest: } \\
\text { - A "market" orientation, including knowledge of products, } \\
\text { customers, and competitors. } \\
\text { - A "value" orientation, to improve the product for customers. }\end{array}$ \\
\hline 4 & $\begin{array}{l}\text { The context of implementation, which should allow the rapid } \\
\text { implementation of good ideas. }\end{array}$ \\
\hline
\end{tabular}

Source: Dobni, 2008. 
The DNA of the innovative organization in the living world carries all the characteristics of a living being.

Figure 3. The three components of innovative culture.

\begin{tabular}{|l|l|}
\hline $\begin{array}{l}\text { The PERSONNEL } \\
\text { Leaders drive innovation and } \\
\text { excel in discovery skills } \\
\text { (discovery quotient> 75\%). } \\
\text { They allocate and follow each } \\
\text { managerial level, in each } \\
\text { function, and at each decision } \\
\text { level concerning innovation, a }\end{array}$ \\
$\begin{array}{l}\text { They are intended to encourage } \\
\text { association, questioning, } \\
\text { observation, networking, and } \\
\text { experimentation. They are } \\
\text { designed to recruit, train, }\end{array}$ \\
\hline
\end{tabular}

\section{THE PHILOSOPHY}

Principle 1: Innovation is everybody's business, not just R\&D

Principle 2: Breakthrough innovation is at the center of the innovation portfolio

Principle 3: Focus on small and structured project teams

Source: Christensen, Dyer and Gregersen, 2013. Adapted.

\subsubsection{The Culture of Innovation in the $21^{\text {st }}$ Century}

Now is the time for collaborative, diverse and intercultural innovation for multiple, diverse, and globalized markets. At the external level of the company, it is necessary to recognize that the value of an innovation project is positively influenced by the (ordered) increase of the number of partners and the fact that they come from horizons and different cultures. This new paradigm comes first and foremost from a change of mind with the key words 'openness to diversity in the process of innovation' (Paun, 2012).

\subsection{Model for the Culture of Innovation}

This model presents components working in a complementary and successive manner such as:

Figure 4. Culture of Innovation Model.

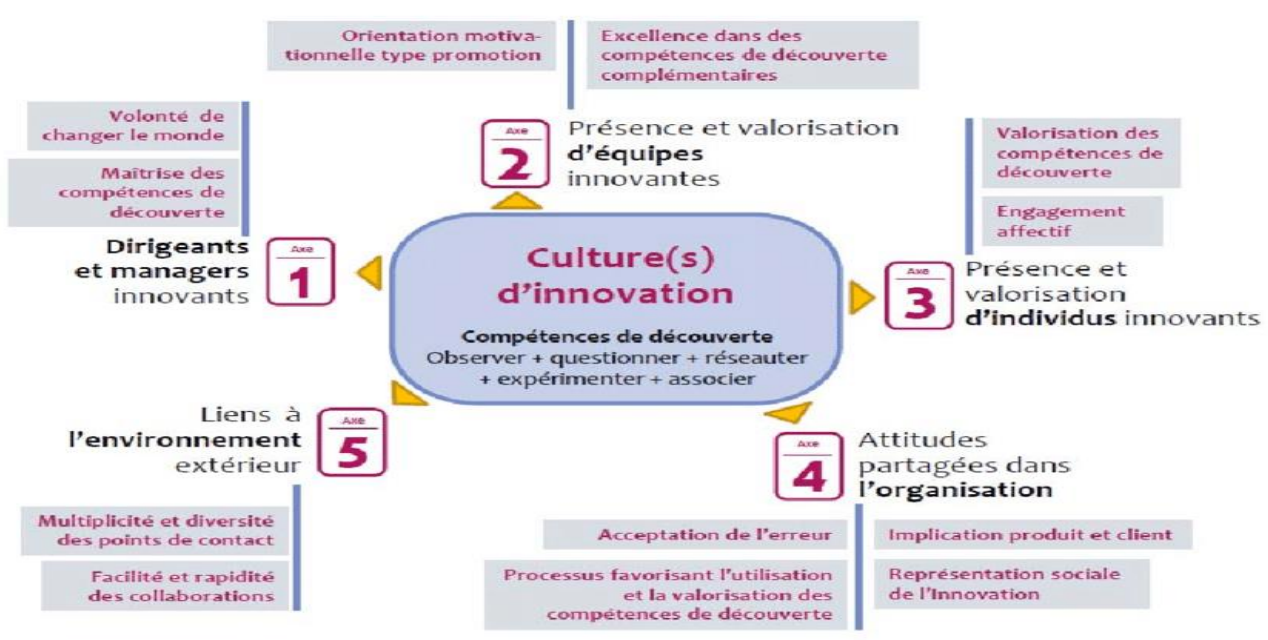

Source: Davies and Buisine, 2017. 


\subsection{The Models of Inno-preneurs}

\subsubsection{Inno-preneurship Platform Model}

This model shows the inno-preneurship platform based on a supply-side ecosystem and demand-side ecosystem.

Figure 5. The inno-preneurship platform.
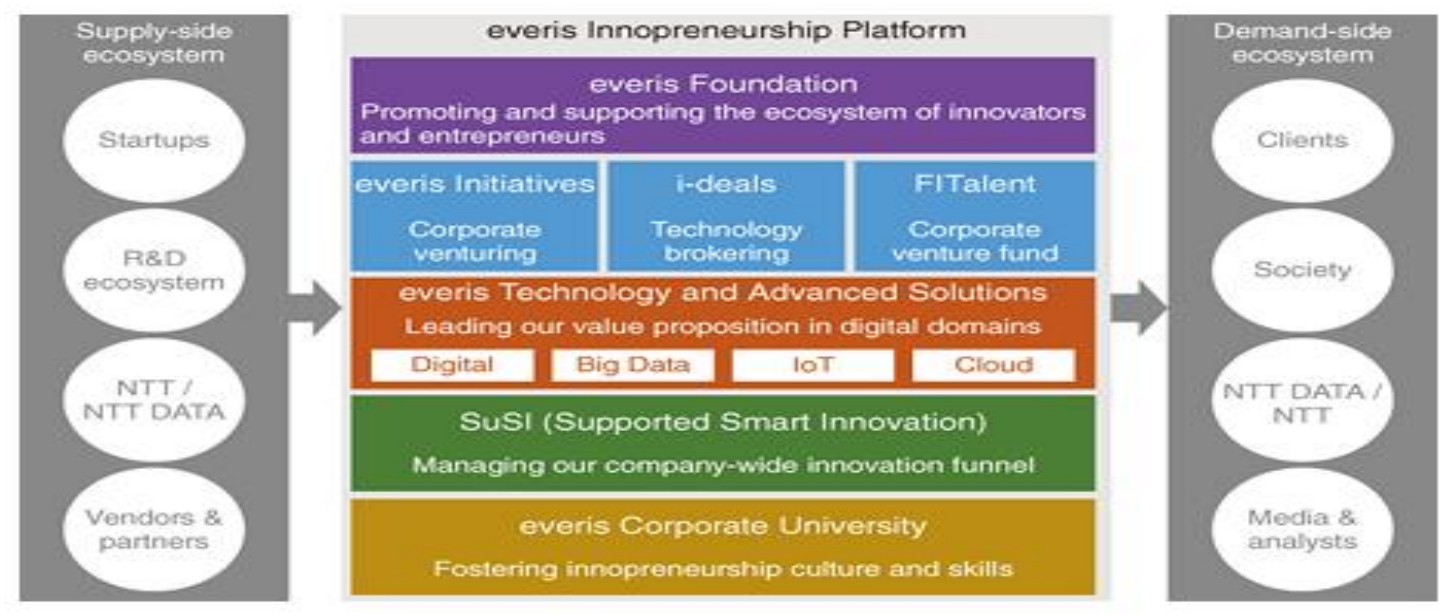

Source: Alba, 2016.

\subsubsection{Inno-preneurs Steps Model}

This model shows the steps of inno-preneurship achieved through 4 steps: Discover, Define, Design, Make a difference.

Figure 6. The Inno-preneurship steps model.

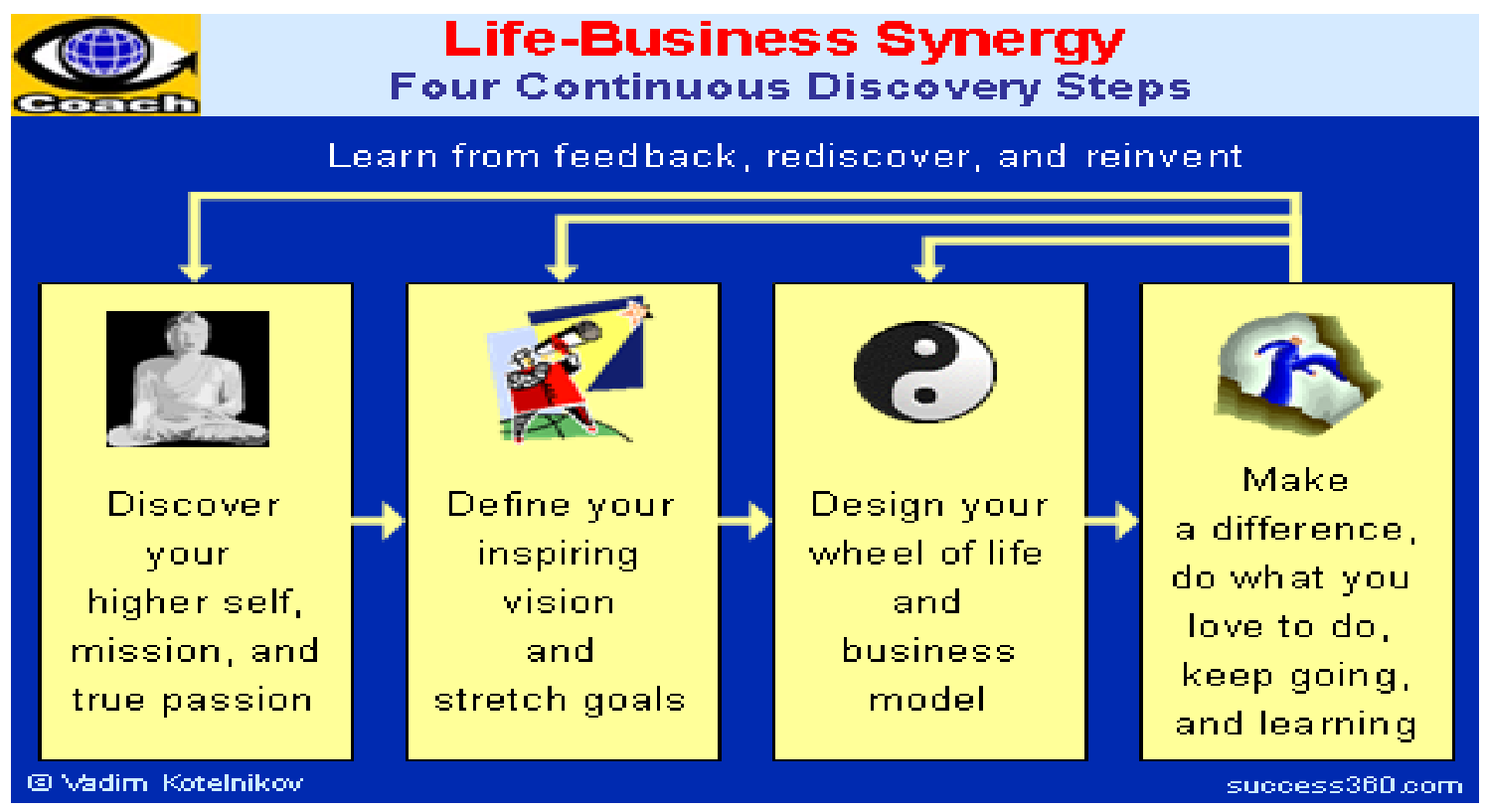

Source: Kotelnikov.Vadim ; Life-Business Synergy,http. 


\section{Results}

\subsection{Case: Inno-Preneuship as a Smart City (Singapore)}

The case of (smart city) is an exemplary case to present, to show the roles of migrant Innopreneurs and their human capital to achieve sustainable development, this is the case of Singapore.

\subsubsection{What is a Smart City?}

Even while the concept of smart cities has been largely linked to digitalization and ICT, Boyd Cohen's 2014 article in 'Fast Company' showed that the top 10 cities around the world that are doing the best are embracing the future by focusing on improving technology, equality, sharing and civic participation. "For many years, the push to create smarter cities was led by technology companies looking for uses (and buyers) for their products," Boyd writes, adding that "in recent years, cities have begun to think more holistically about what being a smart city could mean, and have innovated new ways to modernize how a city serves its citizens". Clearly, while tech is a vital part of smart cities in this era of digital disruption, Inno-preneurs-led transformation is most likely to use technology as a base from which to generate the ideas shared by partners, entrepreneurs and private enterprises to create cities that take socioeconomic factors, human rights and care, and business and job creation into consideration. Truly smart cities have the potential to be breeding grounds for entrepreneurship, the cornerstone of economic growth. The figure below explains the model of smart city which is composed of (6) components; harmonious, interactives, and complementary each other's: Society, Quality of life, Environment, Government, Economy, Mobility.

Figure 7. Smart Cities business model.

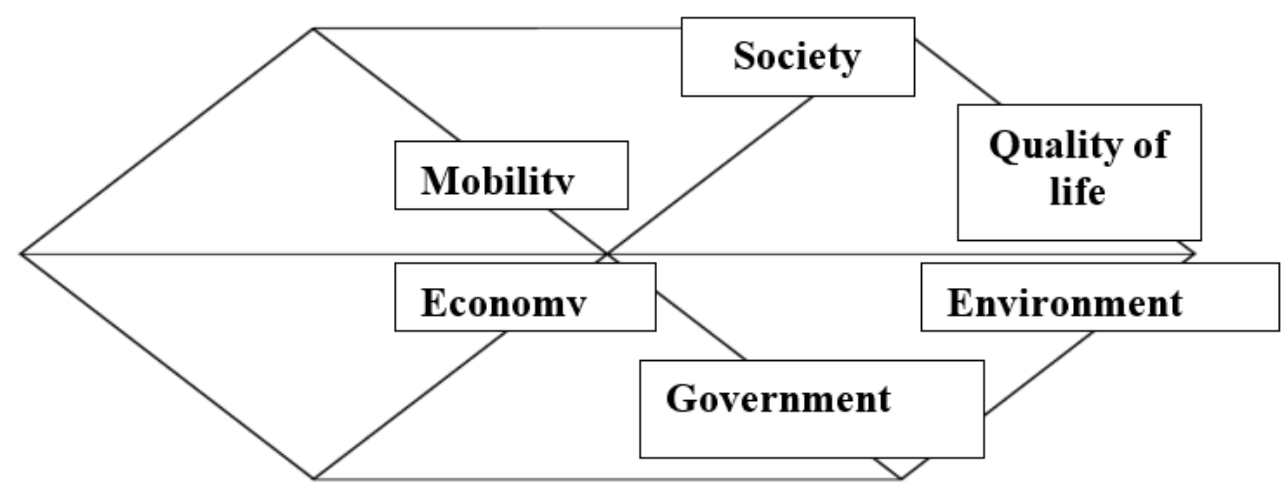

Source: Yu-Jen Chen and Karuri-Sebina, 2017. Adapted.

While innovation requires a thinking and doing process that leads to meeting specific current and future needs, inno-preneurship would be the metaphoric blueprint on which a smart city is built by visualizing something that does not yet exist, working for people who don't yet know that they want the services and opportunities a smart city provides.

The "smart city" has typically been defined as one that uses information and communication technologies (ICT) to create critical infrastructure and public services that are more affordable, accessible, interactive, and efficient. (Yu-Jen Chen \& Karuri-Sebina, 2017). A smart city, therefore, is not merely one that looks good and functions efficiently, it is one that uses technological innovations to empower people to live more fulfilled lives within their contexts. 


\subsubsection{Inno-preneurs / Partners VS Smart City}

Where city innovation managers and economic development managers work together, implementation of the necessary infrastructure and strategies will likely be easier and more beneficial to all parties, particularly where they adopt viable business models already successful in the private or civic sectors to promote inno-preneurial collaboration.

\subsubsection{The case of Singapore City}

It must be noted here that, in the case of Singapore, the government's National Research Foundation is working together with private-sector firms, universities and other government departments, highlighting the importance of overall buy-in from all stakeholders. Reliable funding from governments and from the private sector is the foundation of the critical sustainability on which nations' competitiveness and future preparedness rest. And reliable knowledge from all four sectors; public, private, civic, and knowledge; is the bedrock that ensures contextual relevance and inclusion.

\subsubsection{Inno-preneurs of Singapore City}

Striving to be the world's first smart city - and well on its way-Singapore's Smart Nation programme was launched by Prime Minister Lee Hsien Loong in late 2014. According to a 2015 article published in The Economist, chances of 'smart city' status were remote in 1965 when, as a small and underdeveloped newly independent country, it had a population of relatively recent immigrants with little-shared history and no natural resources to speak of. It is noted that three key drivers made the difference between the Singapore of 1965 and the economically successful powerhouse it is now.

1. Firstly, its harbor and strategic location at the mouth of the Malacca Strait made it an important route for maritime traffic.

2. Secondly, the country's first Prime Minister, the late Lee Kuan Yew, welcomed foreign trade and investment, and global corporations found it to be a natural hub where they were encouraged to prosper and expand, thereby creating jobs.

3. Thirdly, the government was kept small, efficient, and honest and is regularly rated very highly in surveys of ease of doing business. While some have raised personal privacy issues regarding Prime Minister Loong's Smart Nation programme (and these are indeed important issues begging consideration in any democratic country), the innovations on which Singapore is pinned are largely designed for a better quality of life and monitoring by those in a position to quickly take care of services that falter. One such example is sensors deployed by private firms in publicly managed elder-care homes that will alert the family if individuals are not moving as they regularly do and even record bathroom use in an attempt to monitor general health. This would mean quicker action by families and healthcare practitioners, thus, reducing suffering.

Singapore's Minister for Foreign Affairs, Vivian Balakrishnan, FRCS, is also the Minister-incharge of the Smart Nation Programme Office and asserts that the programme is about action and the conducting of trials across many sectors, focusing on" areas with high impact on residents and citizens. In any country, this naturally requires partnerships with various government departments, as well as the corporate and private sectors. Included in these partnerships are partner-accessible divisions that share resources and innovate, collecting data to pre-empt service delivery failure and seamlessly implement new systems as technology becomes available. Though the term "smart city" sounds high-tech and wealthy, it is imperative that any truly smart city across the globe considers the needs of the poor, under-educated and possibly tech challenged. Often, app developers forget this sector, but Inno-preneurs understand the importance of the overall equality of opportunity. 
A city that endorses inno-preneurship is one that provides inclusive services and facilities to its full populace, while innovation requires a thinking and doing process that leads to meeting specific current and future needs, inno-preneurship would be the metaphoric blueprint on which a smart city is built by visualizing something that does not yet exist, working for people who don't yet know that they want the services and opportunities a smart city provides.

Inno-preneurship grows into partnerships between innovation managers, economic development managers, government departmental heads, academic institutions, OEMs, SME implementers, the private sector, entrepreneur incubators and venture capitalists or angel funders and to other aspiring Inno-preneurs. In this way, ideas and funding are spread broadly, encouraging an inno-preneurial mindset - the key to future economic success (Yu-Jen Chen \& Karuri-Sebina, 2017).

\subsection{Practical proposed Model}

The proposed practical model is a contribution to the theoretical research and practical work already done in this topic. The process to apply the model needs successive steps such as:

Figure 8. Proposed practical model.

$\begin{aligned} & \text { 1. Create and understand the culture of inno- } \\
& \text { Preneurship in organizations, which is distinguished } \\
& \text { by specific characteristics different from the culture } \\
& \text { of other. innovators or managers. }\end{aligned}$
\begin{tabular}{|l|l|} 
3. Reinforce the Bloc Competencies of Human resources \\
which is composed of (Knowledge, Experiences, Skills, \\
Well-Being) to be in concordance with of labor market \\
requirements.
\end{tabular}
$\begin{aligned} & \text { 2. Understand and strengthen the } \\
& \text { profiles of Inno-preneurs as } \\
& \text { innovators and entrepreneurs at the } \\
& \text { same time, these profiles must } \\
& \text { correspond to the requirements of the } \\
& \text { labor markets of each country }\end{aligned}$
human capital compatible with the
specificities of each country and its
culture, these models are ways of
working for Inno-preneurs.

5. Professional success of Inno-preneurs = sustainable development in developed countries.

Source: Produced by the author.

\section{Conclusions}

Entrepreneurship is not just a set of behaviors that can be exhibited not only by individuals, but also by large companies with the capacity to invest and achieve innovation continuously. New ideas and practices are launched which have an impact on economic and social vitality at large. At this point, the Inno-preneurs must solve problems of economy and society, culture and even the organization of the company, explore, organize people, and often act rigorously.

Therefore, the culture of Inno-preneurs and their innovative practices contribute to the development of developed countries by:

1. Invent new innovative models in all sectors of economies and societies,

2. Strengthen the competencies of Inno-preneurs leaders in companies and administrations, 
3. Promote the capacities of passion and encourage the spirit of innovation of individuals and organizations,

4. The role of university institutes and faculties must be changed to include innopreneurship and its culture in their programs,

5. Innovation as a smart city (Singapore) is a very good example of the culture of innovation in all countries.

Finally, this research is a scientific and practical contribution to be developed and deepened by scientists and practitioners in the field of inno-preneurship, as well as in entrepreneurship. At this level, researchers are invited to carry out more in-depth research in this area.

\section{References}

Abraham. Shinu Anna, et al (2013) Connections and Complexity: New Approaches to the Archaeology of South Asia, (Walnut Creek, CA: Left Coast Press, 2013), ISBN 978-1-59874-686-0, 430 pp.

Alba, M. (2016). Everis and the Next Generation of Digital. NTT Technical Review, 14(10), 1-5.

Barrus, D. (2012). 3 Keys Leaders Can Use To See The Future [Blog post]. Innovpreneur. Available at: http://innovpreneur.com/?paged=2

- (2012). Inspiring Innovation: Three Ways to Make Unstructured Time Work [Blog post]. Innovpreneur. Available at: http://innovpreneur.com/?paged=2.

- (2012). Applying design thinking to your life [Blog post]. Innovpreneur. Available at: http://innovpreneur.com/?paged=2.

- (2012). Applying design thinking to your life [Blog post]. Innovpreneur. Available at: http://innovpreneur.com/?paged=2.

- (2012). Who should be an Intrapreneur? [Blog post]. Innovpreneur. Available at: http://innovpreneur.com/?paged=2.

- (2016) Who should be an Intrapreneur? [Blog post], Available at: http://theinnopreneurs.com/2016/07/19/hello-world.

- (2017). Vivre de sa passion en 6 étapes, création d'entreprendre, entrepreneur, entreprenariat, Innopreneurs [Blog post]. PME, STARTUP. Availabe at: http://innopreneurs.com/vivre-de-passion-6-etapes/

Beckford Consulting (1992). A Process for the Entrepreneurial Decision? Entrepreneurship, Innovation and Change. Available at: A-Process-for-the-Entrepreneurial-Decision.pdf (beckfordconsulting.com).

Benoît Lévesque. (2008). creativity and innovation: proposal for program that gives the social actor a central role in the fight against exclusion, texte produit pour la commission Européenne dans le cadre du projet social polis, avec la collaboration de Ping Huang (2008).

Berna, J. J. (1960). Industrial entrepreneurship in Madras state. Asia Publishing House. The Bison Gear \& Engineering Corp (2008). Available at: innopreneur.wordpress.com/2008/07/21/inno-preneur-defined

Christensen, C., Dyer, J., \& Gregersen, H. (2013). Le gène de l'innovateur: Cinq compétences qui font la différence. Montreuil: Pearson. City University of Hong Kong. (2017). Tea Gathering of Inno-preneurs' Friday (17th Mar 2017).

Davies, M. \& Buisine, S. (2017). La culture d'innovation dans les organisations française. Technologie et Innovation, 2, 1-12. DOI : https://doi.org/10.21494/ISTE.OP.2017.0160 
Dobni, C. B. (2008). Measuring Innovation Culture in Organizations: The Development and Validation of a Generalized Innovation Culture Construct Using Exploratory Factor Analysis. European Journal of Innovation Management, 11(4), 539-559. DOI: https://doi.org/10.1108/14601060810911156

EUCIS-LLL Lisbon Council. (2000). EUCIS-LLL- position_ Entrepreneurship - mindets. Entrepreneurship and higher education: an employability perspective.

Filion, L.J. (2008). Defining the Entrepreneur Complexity and Multi-Dimensional Systems Some Reflections [Working Paper]. Rogers-J.A.-Bombardier Chair of Entrepreneurship, HEC Montréal.

Hello- world (2016). Who are the Inno-preneurs? July 19, 2016, theinnopreneurs.com /2016/07/19/helloworld.

Hisrich, R. D. (1990). Entrepreneurship/intrapreneurship, American Psychologist, 45(2), 209-222.

Inno-preneurs. (2018). India's most happening-project-ideas competition, 4th Edition. Inno-preneurs 2018 launches by Lemon Ideas. Available at: https://www.innopreneurs.com

Jeff Yu-Jen Chen, J. \& Karuri-Sebina, G. (2017). Innopreneurship: the foundation of the truly smart city. Leadership Magazine.

Kotelnikov.Vadim: Find harmony and happiness in your life and business. Life-Business Synergy,http://kotelnikov.biz/index.html

Kuratko, D., Morris, M. H. \& Schindehutte, M. (2015). Understanding the dynamics of entrepreneurship through framework approaches. Small Business Economics, 45(1), 1-13. DOI: https://doi.org/10.1007/s11187$\underline{015-9627-3}$

Lengsfeld, J. (2019). Digital Era Framework. Available at: joernlengsfeld.com

Le Maire, N. (2013). Entrepreneurship-Innopreneurship-and-Innovation, Human Resources Global Ltd.

Larousse. Dictionnaire Arançais Available at : http://www.larousse.fr/dictionnaires/francais/concept/17875.

Lévesque, B. (2008). Le potentiel d'innovation et de transformation de l'économie sociale : quelques éléments de problématique. Interações (Campo Grande),9(2),191-216. DOI : https://doi.org/10.1590/S1518$\underline{70122008000200008}$

Metrix Research. The Entrepreneur's Journey, https://www.metrix.com.my/.

Mootee. I. (2013). Design Thinking for Strategic Innovation: What They Can't Teach You at Business or Design School. New Jersey: Wiley.

Morrison, A. (2000). Entrepreneurship: What triggers it? International Journal of Entrepreneurial Behaviour $\mathcal{E}$ Research, 6(2), 59-71. DOI: https://doi.org/10.1108/13552550010335976

Paun, F. (2011). The Demand Readiness Level Scale as New Proposed Tool to Hybridize Market Pull with Technology Push Approaches in Technology Transfer Practices. In Audretsch, D., Lehmann, E., Link, A., Starnecker, A. (eds.) Technology Transfer in a Global Economy. International Studies in Entrepreneurship (353-366) Boston: Springer.

Shaun. Abraham son \& al. (2013). Why Should You Become an Inno-preneur? Innovation Management. 
TERMIUM Plus®, the Government of Canada's terminology and linguistic data bank (1992) Economy Subject. Availabe at: https://open.canada.ca/data/en/dataset/94fc74d6-9b9a-4c2e-9c6c-45a5092453aa\#wbauto-6

Vaileanu, I. (2017). Culture Française : Culture d'Innovation du XXIe Siècle [Blog post]. Interview Francophone. Availabe at: https://www.interviewfrancophone.net/post/culture-franaise-culture-dinnovation-du-xxie-siecle

Womeninfocus.com.https://www.womeninfocus.com.au/t5/tkb/articleprintpage/tkbid/LeadershipTKB/article-id/1370.

\section{(9) $\mathbb{\oplus \Theta \Theta}$}

(c) Attribution-NonCommercial-NoDerivatives 4.0 International (CC BY-NC-ND 4.0)

https://creativecommons.org/licenses/by-nc-nd/4.0/ 